\title{
Effect of Growth Regulators on In Vitro Callus Formation of Rosemary Plant (Rosmarinus officinalis L.)
}

\author{
Mohammed Mehdi Muhsen AL MASOODY ${ }^{1,2^{*}}$, Florin STĂNICĂ ${ }^{1)}$ \\ ${ }^{1}$ Faculty of Horticulture, University of Agronomic Sciences and Veterinary Medicine of Bucharest, \\ B-dul Mărăști, nr. 59, 011464, Bucharest, Romania \\ ${ }^{2}$ AL-Musiab Technical College, Foundation of Technical Education, Iraq \\ ${ }^{*}$ Corresponding author, e-mail: aboteabe@yahoo.com
}

Bulletin UASVM Horticulture 72(1) / 2015

Print ISSN 1843-5254, Electronic ISSN 1843-5394

Doi:10.15835/buasvmcn-hort:10981

\begin{abstract}
The study included the use of tissue culture technique in rosemary (Rosmarinus officinalis L.) plant propagation starting from leaf explants and the production of callus. The first experiment consisted in the leaf explants sterilization using ten randomized replications of ethanol $\left(\mathrm{C}_{2} \mathrm{H}_{5} \mathrm{OH}\right)$, mercuric chloride $\left(\mathrm{HgCl}_{2}\right)$ and sodium hypochlorite $(\mathrm{NaOCl})$ respectively, on six concentrations and five treatment periods, each. The results showed that the use of sodium hypochlorite in a concentration of $0.75 \%$ for a period of 15 minutes was the most effective by giving sterile explants after two weeks of culture. After the explants sterilization, the effect of six concentrations of benzyl adenine (BA) and six concentrations of naphthalene acetic acid (NAA) and the overlap between them on the callus formation were studied. Highest callus size $\left(\mathrm{mm}^{3}\right)$, callus fresh and dry weight $(\mathrm{g})$ occurred at $0.2 \mathrm{mg} / \mathrm{l}$ $\mathrm{BA}$ and $1.5 \mathrm{mg} / \mathrm{l}$ of NAA.
\end{abstract}

Keywords: hormones, leaf explant, sterilization.

\section{INTRODUCTION}

Rosemary (Rosmarinus officinalis L.) is a very important medicinal plant which belongs to the Lamiaceae Family and has been cultivated for a long time (Eva et al., 2003). The Lamiaceae family includes an extremely wide variety of aromatic plants, among this rich array of plants yielding essential oils (Chalchate et al., 1993). Medicinal plants are used in crude or purified form in the preparation of drugs in different systems (Robins et al., 1999).

Rosemary is widely used as a culinary spice and is also used for its fragrance in soaps and cosmetics.

Traditionally, rosemary has been used for medicinal cures to improve memory, relieve muscle pain and spasm, stimulate hair growth, support the circulatory and nervous systems (Foster and Tyler, 1999).
The leaves of rosemary contain 1.0-2.5\% essential oils and such composition may vary according to the chemo type and the development stage at which the plant has been harvested. The essential oil is almost colorless to pale yellow liquid with a characteristic refreshing and pleasant odor (Bauer et al., 1997).

Plant cells and callus cultures have been extensively used to explore the possibility of producing useful secondary metabolites through biotechnology methods.

With the stimulus of endogenous growth substances or by addition of exogenous growth regulators to the nutrient medium, cell division, cell growth and tissue differentiation are induced on in vitro cultivated medicinal plants (Leena and Jaindra, 2003). 


\section{MATERIALS AND METHODS}

The study was conducted at the micropropagation laboratory of the Faculty of Horticulture, University of Agronomic Sciences and Veterinary Medicine of Bucharest during the period October 2013 - June 2014 on rosemary plant (Rosmarinus officinalis L).

Explants preparation and sterilization. Leaves of random length $(0.5-1.5 \mathrm{~cm})$ were taken from container grown rosemary plants. For leaves sterilization before the in vitro stabilization three types of chemical sterilizers were used: ethanol $\left(\mathrm{C}_{2} \mathrm{H}_{5} \mathrm{OH}\right)$, mercuric chloride $\left(\mathrm{HgCl}_{2}\right)$ and sodium hypochlorite ( $\mathrm{NaOCl}$ ).

The ethanol was used in ten full random replicates of six concentrations $(20,30,40,50$, 60 and $70 \%)$ and five periods $(0.5,1,2,3$ and 5 minutes).

The mercuric chloride $\left(\mathrm{HgCl}_{2}\right)$ was applied in ten randomized replicates of six concentrations $(0.03,0.06,0.10,0.15,0.20$ and $0.30 \mathrm{mg} / \mathrm{l})$ and five treatment durations of $4,6,8,10$ and 12 minutes.

The leaves sterilization with sodium hypochlorite ( $\mathrm{NaOCl}$ ) was applied following the same experimental design with six concentrations $(0.50,0.25,1.5,1.25,1.0,0.75 \%)$ and five treatment periods (5.10, 15, 20 and 25 minutes respectively). The solution was obtained from the commercial sodium hypochlorite (Clorox) with a content of $5.25 \%$ chlorine.

The explants sterilization was done by solutions continuously stirring. After the end of the sterilization process, leaves were washed with distilled sterilized water for three times.

Preparation of nutrient medium. Murashige \& Skoog medium (MS, 1972) supplemented with sucrose as a source of energy as well as vitamins (Walkey Vitamins) and plant growth regulators was used for explants inoculation.

As growth regulators, $6 \times 6$ combinations of benzyl adenine (BA) and naphthalene acetic acid (NAA) in concentration of $0.0,0.5,1.0,1.5$, 2.0 and respectively, $3.0 \mathrm{mg} / \mathrm{l}$, were added at the culture medium to stimulate callus formation.

Sterilized explants were inoculated on culture media and then placed in an incubation room at $25 \pm 1^{\circ} \mathrm{C}, 1,000$ Lux light intensity and 16 hours daily lighting.

Measurement of the callus size (volume). For measuring the size, the mass callus was extracted by sterile forceps and washed with distilled sterile water several times to remove the remaining culture medium. The block callus was then put inside a graduated cylinder containing sterile distilled water at a given volume and the supplementary volume was recorded and expressed in $\mathrm{mm}^{3}$.

Measurement of the callus fresh weight. The mass callus growth was calculated by the difference between the weight of the culture jar at the end of and at the beginning of the experiment, determined with a sensitive balance.

Estimate the dry weight of callus. After calculating the fresh weight of the soft callus it was placed on filter paper in the oven at $70^{\circ} \mathrm{C}$ for 24 hours. The dry weight was then recorded.

\section{RESULTS AND DISCUSSION}

The effect of ethylic alcohol $\left(\mathrm{C}_{2} \mathrm{H}_{5} \mathrm{OH}\right)$ on rosemary leaves explants sterilization

The results indicated in the Table 1 shows the lack of significant differences between the concentrations of $20 \%, 60 \%$ and $70 \%$ of ethylic alcohol, where the average number of healthy leaves was (1.00, 1.04 and respectively 1.00).

The concentration of $50 \%$ alcohol, gave the highest number of healthy leaves (2.62), while for the sterilization time, the highest average value (1.95 leaves) was obtain at a duration of 3 minutes.

The results also showed that there were no significant differences between the average number of healthy leaves (1.47 and 1.40) when the duration of the sterilization was 1 and respectively, 5 minutes.

The results also showed that the overlap between the alcohol concentration and the treatment duration affected significantly the average number of healthy leaves. The top number of 3.90 healthy leaves was reached when used alcohol concentration of $50 \%$ for 3 minutes.

The increase of alcohol concentration to more than $50 \%$ led to the increase in the number of dead leaves in all the variants, confirming the data published by Kosaka and Yokoi (2003).

The effect of mercuric chloride $\left(\mathrm{HgCl}_{2}\right)$ on rosemary leaves explants sterilization

The results in Table 2 showed that mercuric chloride $\left(\mathrm{HgCl}_{2}\right)$ had a significant effect on leaves sterilization with the best effect at a concentration of $0.06 \mathrm{mg} / \mathrm{l}$ that gave the highest number of healthy leaves (3.52). It was further noted that the period of sterilization affected the number 
of healthy leaves. For 6-8 minutes sterilization time was reached the highest average number of sterile and healthy leaves (2.30) for all used concentrations.

The highest number of healthy sterile leaves (5.10) was obtained at the concentration of $0.06 \mathrm{mg} / \mathrm{l}$ and 6 minutes sterilization time. By increasing the concentration of $\mathrm{HgCl}_{2}$, the number of burned or dead leaves, increased.

It is therefore concluded that, the low concentrations of mercuric chloride led to the contamination of leaves at high rates, either high concentrations determined leaves death and burning due to the toxic effect.
The effect of sodium hypochlorite ( $\mathrm{NaOCl}$ ) on rosemary leaves explants sterilization

The results in the Table 3 indicate significant differences between different concentrations of sodium hypochlorite $(\mathrm{NaOCl})$ and the number of survival leaves after $1 \mathrm{mg} / \mathrm{l}$.

The number of healthy leaves began to decline the greater the duration of sterilization after more than 15 minutes, and reached the highest number of 3.10 leaves when using the concentration of $0.75 \mathrm{mg} / \mathrm{l}$ sodium hypochlorite.

The highest average number of healthy leaves (2.72) was obtained when the duration of sterilization was 15 minutes. The values decline to 1.87 healthy leaves at the duration of 20 minutes

Tab. 1. Effect of the concentration of ethanol $\left(\mathrm{C}_{2} \mathrm{H}_{5} \mathrm{OH}\right)$ solution (\%) and the duration of sterilization (minutes) on the average number of healthy leaves of rosemary.

\begin{tabular}{ccccccc}
\hline & 0.5 & 1 & 2 & 3 & 5 & Mean \\
\hline 0 & & & & & & 0.00 \\
\hline 20 & 0.00 & 0.00 & 0.00 & 0.00 & 0.00 \\
\hline 30 & 1.00 & 1.00 & 1.00 & 1.00 & 1.00 & 1.00 \\
\hline 40 & 1.10 & 1.30 & 1.40 & 1.60 & 1.80 & 1.44 \\
\hline 50 & 1.50 & 1.70 & 3.00 & 3.20 & 1.60 & 2.20 \\
\hline 60 & 1.50 & 2.80 & 3.10 & 3.90 & 1.80 & 2.62 \\
\hline 70 & 1.00 & 1.00 & 1.00 & 1.00 & 1.20 & 1.04 \\
\hline Mean & 1.18 & 1.00 & 1.00 & 1.00 & 1.00 & 1.00 \\
\hline LSD $\leq 0.05$ & 1.47 & 1.75 & 1.95 & 1.40 & \\
\hline \multicolumn{2}{c}{$\mathrm{C}_{2} \mathrm{H}_{5} \mathrm{OH}=0.1814$} & Time $=0.1534$ & $\mathrm{C}_{2} \mathrm{H}_{5} \mathrm{OH} \times$ Time $=0.4057$ \\
\hline
\end{tabular}

Tab. 2. Effect of the concentration of mercuric chloride (mg/l) and the duration of sterilization (minutes) on the average number of healthy leaves of rosemary.

\begin{tabular}{|c|c|c|c|c|c|c|}
\hline \multicolumn{7}{|l|}{ Time } \\
\hline $\mathrm{HgCl}_{2}$ & 4 & 6 & 8 & 10 & 12 & Mean \\
\hline 0.00 & 0.00 & 0.00 & 0.00 & 0.00 & 0.00 & 0.00 \\
\hline 0.03 & 1.90 & 1.80 & 1.60 & 1.10 & 1.00 & 1.48 \\
\hline 0.06 & 2.90 & 5.10 & 4.00 & 3.40 & 2.20 & 3.52 \\
\hline 0.10 & 2.70 & 3.50 & 3.20 & 1.60 & 1.10 & 2.42 \\
\hline 0.15 & 1.60 & 1.20 & 1.10 & 1.00 & 1.00 & 1.18 \\
\hline 0.20 & 1.40 & 1.20 & 1.00 & 1.00 & 1.00 & 1.12 \\
\hline 0.30 & 1.00 & 1.00 & 1.00 & 1.00 & 1.00 & 1.00 \\
\hline Mean & 1.92 & 2.30 & 2.30 & 1.52 & 1.22 & \\
\hline $\mathrm{LSD} \leq 0.05$ & \multicolumn{2}{|c|}{$\mathrm{HgCl}_{2}: 0.1401$} & \multicolumn{2}{|c|}{ Time:0.1148 } & $\mathrm{HgCl}_{2} \times \mathrm{Tin}$ & 332 \\
\hline
\end{tabular}


while the lowest number of 1.33 leaves was reached at 25 minutes sterilization time (Caruso et al., 2000).

The results of statistical analysis showed that the overlap between the variants has affected the average number of healthy leaves, best result being of 5.00 leaves when using a solution of $0.75 \mathrm{mg} / \mathrm{l}$ sodium hypochlorite for a period of 15 minutes.

Used by many researchers, the solution of sodium hypochlorite for superficial sterilization of plant parts was efficient and didn't damage the explants at appropriate concentrations (Gertlowski et al., 1993). These findings are similar with those of Hippolyte. (2000), which pointed out that the high concentrations of sodium hypochlorite can be effective in sterilizing the superficial plant parts cultivated in vitro, but it is accompanied by the death of plant parts. The reason may be attributed to the different type of plant and to the degree of persistent injury.

The effect of BA and NAA and the overlap between them on the rosemary callus volume $\left(\mathrm{mm}^{3}\right)$

Data shown in Table 4 indicate that the levels of BA and NAA and overlap of two, significantly affected the volume of formed callus. The concentration of $1.5 \mathrm{mg} / \mathrm{l} \mathrm{BA}$ gave the highest volume of callus $\left(8.4 \mathrm{~mm}^{3}\right)$, which was superior to the average volume of callus produced by different concentrations of NAA $\left(1.68 \mathrm{~mm}^{3}\right)$.

It is noted in the same table that, the highest volume of callus was $6.1 \mathrm{~mm}^{3}$ at concentrations of 1.5 and $2.0 \mathrm{mg} / \mathrm{l}$ of NAA and the lowest volume $\left(1.1 \mathrm{~mm}^{3}\right)$ at $0.0 \mathrm{mg} / \mathrm{l} \mathrm{NAA}$.

By increasing the concentrations of $\mathrm{BA}$ and NAA to $2.0 \mathrm{mg} / \mathrm{l}$ or more, the callus size reduced and this shown that high concentrations led to

Tab. 3. The effect of the concentration of sodium hypochlorite $\mathrm{NaOCl}(\mathrm{mg} / \mathrm{l})$ and duration of sterilization (minutes) and overlap on the average number of healthy leaves of rosemary.

\begin{tabular}{ccccccc}
\hline Time & 5 & 10 & 15 & 20 & 25 & Mean \\
\hline 0.00 & 0.00 & 0.00 & 0.00 & 0.00 & 0.00 & 0.00 \\
\hline 0.25 & 1.00 & 1.00 & 1.80 & 1.60 & 1.00 & 1.28 \\
\hline 0.50 & 1.60 & 2.00 & 3.40 & 2.10 & 1.60 & 2.14 \\
\hline 0.75 & 2.00 & 3.00 & 5.00 & 3.50 & 2.00 & 3.10 \\
\hline 1.00 & 1.60 & 2.40 & 3.60 & 2.00 & 1.40 & 2.20 \\
\hline 1.25 & 1.40 & 1.40 & 1.50 & 1.00 & 1.00 & 1.26 \\
\hline 1.50 & 1.00 & 1.00 & 1.00 & 1.00 & 1.00 & 1.00 \\
\hline Mean & 1.43 & 1.80 & 2.72 & 1.87 & 1.33 & \\
\hline LSD $\leq 0.05$ & $\mathrm{NaOCl}=0.1004$ & Time $=0.1188$ & & NaOCl $\times$ Time $=0.2713$ \\
\hline
\end{tabular}

Tab. 4. Effect of NAA and BA and overlap on callus volume $\left(\mathrm{mm}^{3}\right)$.

\begin{tabular}{cccccccc}
\hline $\begin{array}{c}\text { NAA (mg/l) } \\
\text { BA (mg/l) }\end{array}$ & 0.0 & 0.5 & 1.0 & 1.5 & 2.0 & 3.0 & $\begin{array}{c}\text { Average } \\
\text { BA }\end{array}$ \\
\hline 0.0 & 0.0 & 2.0 & 2.2 & 2.4 & 1.9 & 1.6 & 1.68 \\
\hline 0.5 & 0.9 & 2.6 & 2.9 & 3.5 & 4.4 & 2.3 & 2.76 \\
\hline 1.0 & 1.2 & 3.1 & 3.7 & 4.3 & 6.1 & 2.9 & 3.55 \\
\hline 1.5 & 1.6 & 6.2 & 7.4 & 14.4 & 11.5 & 9.3 & 8.40 \\
\hline 2.0 & 1.3 & 3.3 & 6.9 & 6.2 & 7.5 & 8.2 & 5.56 \\
\hline 3.0 & 1.1 & 2.6 & 5.4 & 3.5 & 5.4 & 7.5 & 4.25 \\
\hline Average NAA & 1.1 & 3.3 & 4.8 & 6.1 & 6.1 & 5.3 & \\
\hline LSD $\leq 0.05$ & & BA $=0.1532$ & NAA $=0.1532$ & \multicolumn{3}{c}{ BA x NAA $=0.3754$} \\
\hline
\end{tabular}


inhibit the callus growth. The variants free of NAA determined the severe inhibition of cells, leading to weak growth. The overlap between BA and NAA

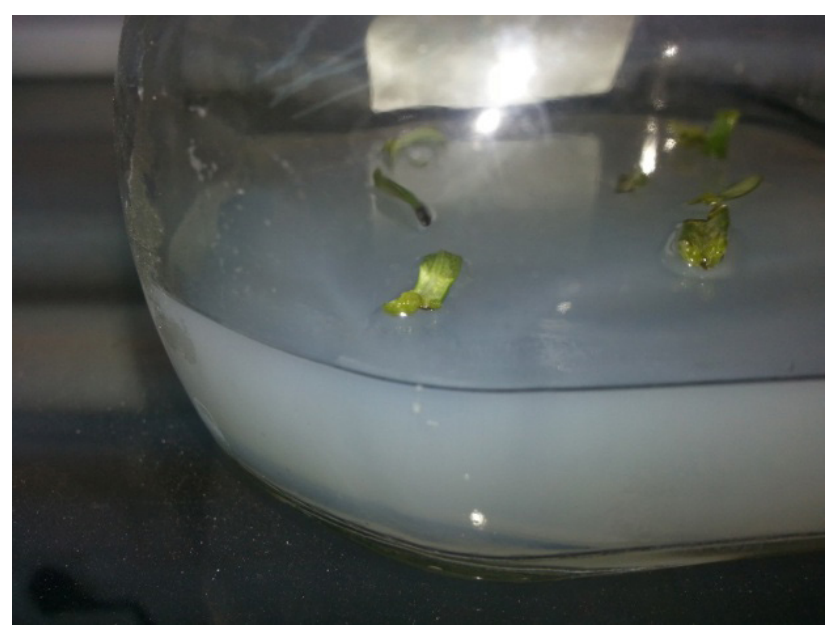

in concentration of $1.5 \mathrm{mg} / \mathrm{l}$ each, produced the highest callus volume of $14.4 \mathrm{~mm}^{3}$.

Effect of BA and NAA and the overlap between them on the rosemary callus fresh weight (g).

The Table 5 shows that, the treatment with BA and NAA have led to a significant increase in the fresh weight of the soft callus (g). The concentration of $2.0 \mathrm{mg} / \mathrm{l} \mathrm{BA}$ determined an increase in callus fresh weight of $0.68 \mathrm{~g}$ compared with only 0.32 $\mathrm{g}$ in the control treatment. The levels of NAA has significantly affected the fresh weight of callus reaching a top value of $0.75 \mathrm{~g}$ at a concentration of $1.5 \mathrm{mg} / \mathrm{l}$ and only $0.11 \mathrm{~g}$ for control.

The highest impact of the overlap between BA and NAA on the callus fresh weight was obtained at $2.0 \mathrm{mg} / \mathrm{l} \mathrm{BA}$ and $1.5 \mathrm{mg} / \mathrm{l} \mathrm{NAA}$ with a growth of $1.53 \mathrm{~g}$.

Fig. 1. Rosemary callus formation after the sterilization process.

Tab. 5. Effect of BA and NAA and overlap on callus fresh weight (g).

\begin{tabular}{|c|c|c|c|c|c|c|c|}
\hline BA (mg/l) & 0.0 & 0.5 & 1.0 & 1.5 & 2.0 & 3.0 & $\begin{array}{c}\text { Average } \\
\text { BA }\end{array}$ \\
\hline 0.0 & 0.00 & 0.29 & 0.28 & 0.51 & 0.64 & 0.20 & 0.32 \\
\hline 0.5 & 0.09 & 0.62 & 0.41 & 0.59 & 0.83 & 0.31 & 0.47 \\
\hline 1.0 & 0.13 & 0.34 & 0.72 & 0.73 & 0.53 & 0.32 & 0.46 \\
\hline 1.5 & 0.14 & 0.39 & 0.81 & 0.74 & 0.23 & 1.05 & 0.49 \\
\hline 2.0 & 0.16 & 0.44 & 0.42 & 1.53 & 0.63 & 0.93 & 0.68 \\
\hline 3.0 & 0.18 & 0.24 & 0.62 & 0.42 & 1.32 & 0.82 & 0.60 \\
\hline Average NAA & 0.11 & 0.39 & 0.52 & 0.75 & 0.69 & 0.60 & \\
\hline $\mathrm{LSD} \leq 0.05$ & & $\mathrm{BA}=0.0137$ & & $\mathrm{NAA}=0.0137$ & & $\mathrm{AA}=0$ & \\
\hline
\end{tabular}

Tab. 6. Effect of BA and NAA and overlap on the rosemary callus dry weight (g).

\begin{tabular}{cccccccc}
\hline $\begin{array}{c}\text { NaAA(mg/l) } \\
\text { BA (mg/h) }\end{array}$ & 0.0 & 0.5 & 1.0 & 1.5 & 2.0 & 3.0 & $\begin{array}{c}\text { Average } \\
\text { BA }\end{array}$ \\
\hline 0.0 & 0.00 & 0.10 & 0.12 & 0.22 & 0.29 & 0.09 & 0.13 \\
\hline 0.5 & 0.04 & 0.23 & 0.19 & 0.24 & 0.37 & 0.10 & 0.19 \\
\hline 1.0 & 0.06 & 0.21 & 0.39 & 0.38 & 0.22 & 0.11 & 0.23 \\
\hline 1.5 & 0.07 & 0.17 & 0.20 & 0.32 & 0.10 & 0.37 & 0.27 \\
\hline 2.0 & 0.08 & 0.13 & 0.31 & 0.13 & 0.63 & 0.44 & 0.28 \\
\hline 3.0 & 0.08 & 0.09 & 0.29 & 0.21 & 0.29 & 0.48 & 0.24 \\
\hline Average NAA & 0.055 & 0.160 & 0.250 & 0.3208 & 0.3227 & 0.260 & \\
\hline LSD 0.05 & \multicolumn{3}{c}{$\mathrm{BA}=0.0263$} & \multicolumn{3}{c}{ NAA $=0.0263$} & \multicolumn{3}{c}{ BAA $=0.0263$} \\
\hline
\end{tabular}




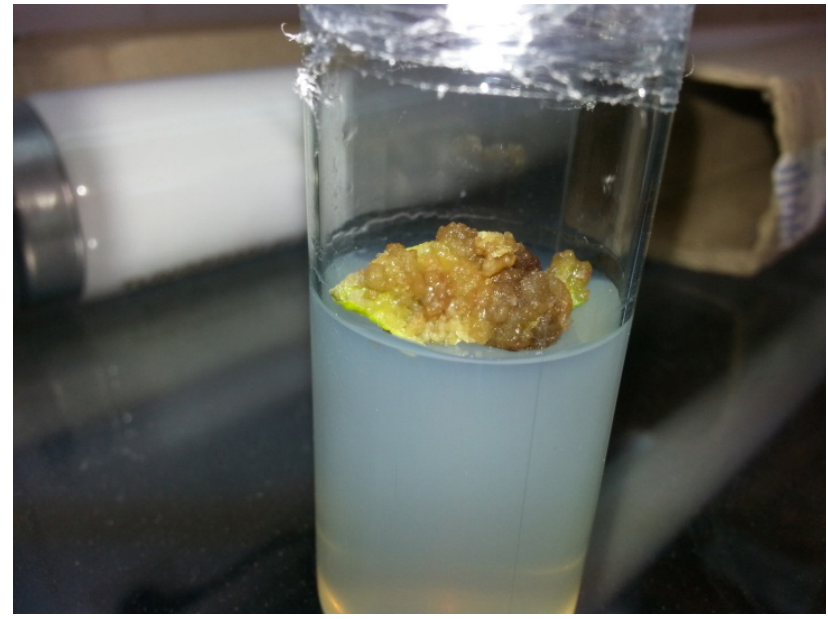

Fig. 2. Rosemary callus produced under the effect of BA and NAA treatment.

Effect of BA and NAA and the overlap between them on rosemary callus dry weight (g).

The results shown in Table 6 underline that the treatment of BA and NAA have led to a significant increase in callus dry weight. The concentration of $2.0 \mathrm{mg} / \mathrm{l} \mathrm{BA}$ had a significant effect on callus dry weight growth $(0.28 \mathrm{~g})$, while the lowest rate $(0.13$ g) was registered in the control treatment.

Similar results, with a value of callus dry weight which stood above $0.32 \mathrm{~g}$, were registered at a concentration of $1.5 \mathrm{mg} / \mathrm{l}$ NAA.

The overlap between BA and NAA had significant effect on the callus dry weight $(0.63 \mathrm{~g})$, at $1.5 \mathrm{mg} / \mathrm{l}$ of BA and $2.0 \mathrm{mg} / \mathrm{l}$ of NAA. No increase in callus dry weight was registered at control treatment.

\section{CONCLUSIONS}

The recommended concentration of ethylic alcohol for rosemary leaves explant sterilization is $50 \%$ for a duration of 3 minutes.

The mercuric chloride $\left(\mathrm{HgCl}_{2}\right)$ gave the highest number of healthy sterile rosemary leaves (5.10) at the concentration of $0.06 \mathrm{mg} / \mathrm{l}$ and 6 minutes sterilization time. By increasing the concentration of $\mathrm{HgCl}_{2}$, the number of burned or dead leaves increased.

The highest average number of healthy rosemary leaves (2.72) was obtained when the sodium hypochlorite $(\mathrm{NaOCl})$ was used at a concentration of $0.75 \mathrm{mg} / \mathrm{l}$ for a sterilization duration of 15 minutes.

Callus growth expressed by callus volume $\left(\mathrm{mm}^{3}\right)$, callus fresh and dry weight $(\mathrm{g})$ was significantly influenced by the combination of BA and NAA. Best results were obtained at concentrations of $2.0 \mathrm{mg} / \mathrm{l} \mathrm{BA}$ and $1.5 \mathrm{mg} / \mathrm{l} \mathrm{NAA}$.

\section{REFERENCES}

1. Areias F, Valentao P, Andrate PB, Ferreres F, Seabra RM (2000). Flavonoids and phenolic acids of sage: Influence of some agriculture factors. J Agric Food Chem 48:60816084.

2. Aruoma OI, Spencer JPE, Rossi R, Aeschbach R, Khan A, Mahmood N, Munoz A, Murcia A, Butler J, Halliwell B (1996). An evaluation of the antioxidant and antiviral action of extracts of rosemary and Provencal herbs. Food Chem Toxicol 34:449-456.

3. Bauer K, Garbe D and Surburg H (1997). Common Fragrance and Flavor Materials. 3rd ed. Germany: WileyVCH.

4. Caruso JL, Callahan J, De Chant C, Jayasimhulu K, Winget GD (2000). Carnosic acid in green callus and regenerated shoots of Rosmarinus officinalis. Plant Cell Rep 19:500503.

5. Chalchate JCO, Garry RP, Michet A, Benjilali B and Chabart JI (1993). Essential oils of rosemary (Rosmarinus officinalis L.). The chemical Gas Chromatography-Mass Spectrometry (GC-MS) Analysis of Active Compounds Produced From Rosemary (Rosmarinus officinalis L.) Callus and Leaf Extracts Salah 118 composition of oils of various origins (Morocco, Spain, France). J. Essential Oil Rosmarinus, 5:613-618.

6. Chen DM and Kang XP (2009). Eco-adaptability and reproduction technique of Rosmarinus officinalis in Qiannan Region of Guizhou, Guizhou Nongye Kexue (Guizhou Agricultural Sciences), 37 (5):25-27.

7. Cuvelier ME, Richard H, Berset C (1996). Antioxidative activity and phenolic composition of pilot-plant and commercial extracts of sage and rosemary. J Am Oil Chem Soc 73:645-652.

8. De-Eknamkul W, Ellis BE (1984). Rosmarinic acid production and growth characteristics of Anchusa officinalis cell suspension cultures. Planta Med 51:346350.

9. Djenane D, Sánchez-Escalante A, Beltrán JA and Roncalés P (2003). Extension of the shelf life of beef steaks packaged in a modified atmosphere by treatment with rosemary and displayed under UV-free lighting, Meat Science, 64(4):417-426.

10. Eva SB, Maria HT, Attila H, Csilla R and Szollosi V (2003). Antioxidant effect of various rosemary (Rosmarinus officinalis L.) clones. Acta Biologica szegediensis, 47(14):111-113.

11. Foster S and Tyler V (1999). The honest herbal; A sensible guide the use of herbs and related remedies. 4th ed. Haworth Herbal Press., 321-322. 
12. Gertlowski K, Petersen M (1993). Influence of the carbon source on growth and rosmarinic acid production in suspension cultures of Coleus blame. Plant Cell Tiss Org 34:183-190.

13. Hidalgo PJ, Ubera JL, Tena MT, Valcarcel M (1998). Determination of the carnosic acid content in the wild and cultivated Rosmarinus officinalis. J Agric Food Chem 46:2624-2627.

14. Hippolyte I (2000). In vitro rosmarinic acid production. In: Kintzios SE, ed., Sage: The Genus Salvia. Amsterdam, Harwood Academic Publishers, pp. 233-242.

15. Kosaka K, Yokoi T (2003). Carnosic acid, a component of rosemary (Rosmarinus officinalis L.) promotes synthesis of nerve growth factor in T98G human glioblastoma cells. Biol Pharm Bull 26:1620-1622.

16. Leena T and Jaindra NT (2003). Role of biotechnology in medicinal plants. Tropical Journal of Pharma. Res., 2(2):243-253

17. Li XC, Zhang HT, Zhou LH, Li XW, Lin XP and Zeng L (2006). Tissue culture techniques of buds in Rosmarinus officinalis L., Jingjilin Yanjiu (Economic Forest Researches), 24(3):15-20.

18. Martinez-Velazquez M, Rosario-Cruz R, CastilloHerrera G, Flores-Fernandez JM, Alvarez AH and Lugo-Cervantes E (2011). Acaricidal effect of essential oils from Lippia graveolens (Lamiales: Verbenaceae), Rosmarinus officinalis (Lamiales: Lamiaceae) and Allium sativum (Liliales: Liliaceae) against Rhipicephalus (Boophilus) microplus (Acari: Ixodidae), Journal of Medical Entomology, 48(4):822-827.

19. Muller M (2004). Formation of antioxidants and essential oil in sage and rosemary grown under Mediterranean and Central European climate. Thesis, Kiel: ChristianAlbrechts-Universitat, Agrar-und Ernahrungswissenschaftliche Fakultat.
20. Munne'-Bosch S, Alegre L, Schwarz K (2000). The formation of phenolic diterpenes in Rosmarinus officinalis L. under Mediterranean climate. Eur Food Res Technol 210:263-267.

21. Munne'-Bosch S, Schwarz K, Alegre L (1999). Response of abietane diterpenes to stress in Rosmarinus officinalis L.: New insights into the function of diterpenes in plants. Free Radical Res 31:107-112.

22. Omri AEL, Han J, Ben Abdrabbah $M$ and Isoda $H$ (2011). Down regulation effect of Rosmarinus officinalis polyphenols on cellular stress proteins in rat pheochromocytoma PC12 cells, Cytotechnology (doi: 10.1007/s10616-011-9352-y).

23. Rasooli I, Fakoor MH, Yadegarinia D, Gachkar L, Allameh A and Rezaei MB (2008) Antimycotoxigenic characteristics of Rosmarinus officinalis and Trachyspermum copticum L. essential oils, International journal of food microbiology,122(1-2):135-139.

24. Robins RL (1999). Secondary products from cultured cells and organs: Molecular and cellular approaches. In: Dixon, R. A., Gonzates, R. A. (eds). Plant Cell Culture. Oxford; IRL, Press.

25. Shabtay A, Sharabani H, Barvish Z, Kafka M, Amichay D, Levy J, Sharoni Y, Uskokovic MR, Studz-inski GP, Danilenko M (2008). Synergistic antileukemic activity of carnosic acid-rich rosemary extract and the 19-nor Gemini vitamin $\mathrm{D}$ analogue in a mouse model of systemic acute myeloid leukemia. Oncology. 75:203-214.

26. Zhang S.H., Weng J.Z., Lin JB, Chen YK and Lin JG (2006). Techniques for tissue culture and rapid propagation of rosemary (Rosemarinus officinalis L.), Guangxi nongye kexue (Guangxi Agricultural Sciences), 37(2):111-112. 